\title{
Low protein diet and chronic renal failure in Buddhist monks
}

\author{
VISITH SITPRIJA, RAMPAI SUVANPHA
}

\begin{abstract}
Clinical observations were made in five Buddhist monks with chronic renal failure on a low protein diet. These monks consumed only one meal and meditated three to four times a day. The estimated protein intake was from 15 to $19 \mathrm{~g}$ a day. Renal function remained stable over three years of observation. The general condition was satisfactory without any evidence of protein energy malnutrition. The data were compared with those of another group of patients who had a comparable degree of impairment of renal function but who consumed three meals a day of low protein diet. Protein intake was estimated to be from 25 to $30 \mathrm{~g}$ a day. These patients developed uraemia with severe renal failure and protein deficiency within three years.

The findings support the role of protein restriction in maintenance of renal function in chronic renal failure and perhaps suggest a beneficial role for meditation.
\end{abstract}

\section{Introduction}

Chronic renal disease usually progresses to chronic renal failure and uraemia. The mechanisms responsible for the progress of the renal lesion are not understood. Though active inflammatory

\footnotetext{
Department of Medicine, Chulalongkorn Hospital Medical School, Bangkok, Thailand

VISITH SITPRIJA, MD, FACP, professor

RAMPAI SUVANPHA, MD, assistant professor

Correspondence to: Dr Visith Sitprija, Department of Medicine, Chulalongkorn Hospital Medical School, Rama 4 Road, Bangkok 10500, Thailand.
}

processes due to immunological activity, infection, hypertension, or superimposing insults may be responsible for the progressive destruction of the nephrons, in most cases the destruction continues despite the quiescence of inflammation and the control of hypertension.

Recently, interest has focused on the role of diet in the progress of renal disease. Restriction of phosphorus in diet has been shown to prevent parenchymal calcification and deterioration of renal function. ${ }^{12}$ A low protein diet has been effective in preventing functional renal impairment in animal models ${ }^{3}{ }^{4}$ and in delaying the clinical course of chronic renal failure in man. ${ }^{5}$ As a very low protein intake may lead to protein energy malnutrition, there are limitations to this form of management. We observed the clinical course of chronic renal failure in Buddhist monks who consumed only one low protein meal daily.

\section{Patients and methods}

A prospective study was undertaken in five Buddhist monks; ages ranged from 44 to 60 years, and duration of service as a monk from 20 to 34 years. All had chronic renal failure with small kidneys shown on intravenous pyelography and all had hypertension with blood pressure ranging from $140 / 90 \mathrm{~mm} \mathrm{Hg}$ to $150 / 100 \mathrm{~mm} \mathrm{Hg}$. These monks lived in rural areas and consumed only one meal daily; the food eaten was high in carbohydrate but very low in protein. In addition, they meditated three to four times daily by concentrating the mind on one thing ${ }^{7}$ and each meditation lasted for two to three hours.

The monks were studied for three years; they were assessed every six months if possible or at their convenience when they visited Bangkok. At each visit samples were taken for measurement of serum creatinine, calcium, phosphate, and albumin concentrations, alkaline phosphatase activity, blood urea nitrogen, complement component (C3), haemolytic component $\left(\mathrm{CH}_{50}\right)$, and haemoglobin concentration. In addition, a 24 hour urine sample was collected to determine concentrations of urea nitrogen, creatinine, sodium, protein, and phos- 
phate. Patients were also weighed and underwent a bone survey.

The data for the monks were compared with those for five patients of comparable age and weight with chronic glomerulonephritis and a comparable degree of renal failure. They were also on a low protein diet but ate three meals a day and did not meditate. These five patients were used as controls.

In the third year of the study serum samples were taken from two monks and two controls for estimation of parathyroid hormone concentrations by radioimmunoassay (courtesy of Dr John F Moorhead, Royal Free Hospital, London).

\section{Results}

Table I shows the laboratory data for the monks and the controls. Figures are means (SEM) for the five cases over each of the three years of the study. In the monks the blood urea nitrogen and serum creatinine concentrations increased minimally but not significantly over the study period. Serum calcium, phosphate and albumin concentrations, $\mathrm{CH}_{50}, \mathrm{C} 3$, alkaline phosphatase activity, haemoglobin concentration, and body weight were essentially unchanged. Figure 1 shows relation between creatinine concentrations and time. In the controls, however, blood urea nitrogen and serum creatinine concentrations increased considerably; serum calcium concentration decreased while serum phosphate and alkaline concentrations rose; serum albumin concentration, haemoglobin concentration, complement, and body weight all decreased. All patients had uraemia. Ordinary $x$ ray technique showed no bone change. Figure 2 shows relation between creatinine concentrations and time.

Of the two monks whose parathyroid hormone concentration had been measured, one had a concentration of $980 \mathrm{ng} / \mathrm{l}$ (and serum creatinine of $353 \mu \mathrm{mol} / \mathrm{l}(4.0 \mathrm{mg} / 100 \mathrm{ml})$ ) and the other had a concentration of $890 \mathrm{ng} / \mathrm{l}$ with $\mathrm{N}$-terminal parathyroid hormone concentration of $87 \mathrm{ng} / \mathrm{l}$ (serum creatinine of $371 \mu \mathrm{mol} / 1(4 \cdot 2 \mathrm{mg} / 100 \mathrm{ml})$ ). Of the two controls, one had a serum parathyroid hormone concentration of $1250 \mathrm{ng} / 1$ (serum creatinine of $716 \mu \mathrm{mol} / 1(8.1 \mathrm{mg} / 100 \mathrm{ml})$ ) and the other had a serum parathyroid hormone concentration of $1208 \mathrm{ng} / 1$ with $\mathrm{N}$-terminal parathyroid hormone concentration of $161 \mathrm{ng} / \mathrm{l}$ (serum creatinine of $813 \mu \mathrm{mol} / 1(9 \cdot 2 \mathrm{mg} / 100 \mathrm{ml})$ ). Normal range of serum parathyroid hormone is $250-950 \mathrm{ng} / \mathrm{l}$, with $\mathrm{N}$-terminal value below $120 \mathrm{ng} / \mathrm{l}$.

Table II shows the urinary data for the monks and controls. In the monks urea nitrogen and protein remained fairly constant and creatinine clearance decreased minimally but not significantly.
Excretion of sodium varied from 59.4 to $64.7 \mathrm{mmol}(\mathrm{mEq}) / 24 \mathrm{~h}$, representing a low sodium intake, and the mean total solute varied from 246.7 to $257.4 \mathrm{mmol}(\mathrm{mosmol}) / 24 \mathrm{~h}$, indicating low excretion of solute. Fractional excretion of phosphate ranged from 13.2 to $14.9^{\prime \prime} \%$ and urinary phosphate concentration from 7.0 to $7.8 \mathrm{mmol} / 24 \mathrm{~h}$ ( 217.7 to $241.9 \mathrm{mg} / 24 \mathrm{~h}$ ).

In contrast, remarkable changes were observed in controls (table II). Creatinine clearance decreased from 34.8 to $8.2 \mathrm{ml} / \mathrm{min}$, while fractional excretion of phosphate increased from 21.7 to $48.1 \%$.

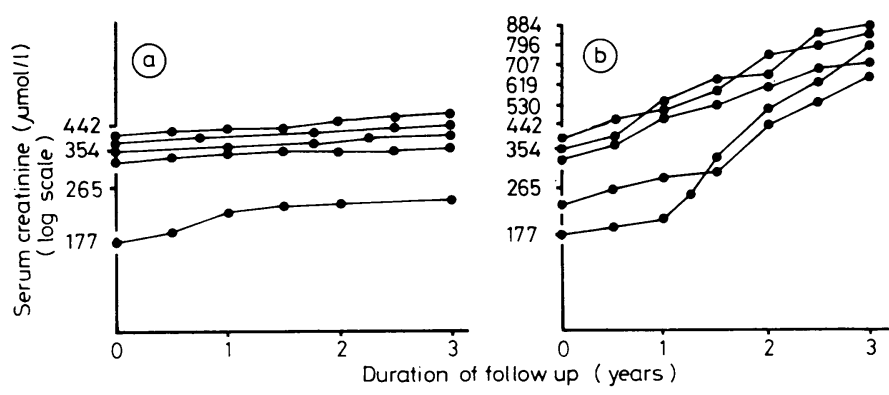

Relation between serum creatinine and time in Buddhist monks (a) and in ordinary patients $(b)$.

Urinary urea nitrogen and sodium concentrations were essentially unchanged; protein intake was estimated to be around 25 to $30 \mathrm{~g}$ /day. Urinary phosphate excretion ranged from 11.4 to $13.6 \mathrm{mmol}(353.8$ to $422.3 \mathrm{mg}) / 24 \mathrm{~h}$. The mean total solute excretion ranged from $414 \cdot 3$ to $489 \cdot 3 \mathrm{mmol}(\mathrm{mosmol}) / 24 \mathrm{~h}$.

\section{Discussion}

Our findings clearly show the slow progress of chronic renal failure in the Buddhist monks who ate one meal a day. The low urinary excretion of urea nitrogen reflected the low protein intake; based on the fact that the patients were in a steady state of nitrogen balance, the protein intake is estimated from nitrogen

TABLE I-Laboratory data for five Buddhist monks and five other patients with chronic renal failure (controls). Results are means (SE) for each group for each year of the study period

\begin{tabular}{|c|c|c|c|c|c|c|}
\hline & \multicolumn{2}{|c|}{ Year 1} & \multicolumn{2}{|c|}{ Year 2} & \multicolumn{2}{|c|}{ Year 3} \\
\hline & Monks & Controls & Monks & Controls & Monks & Controls \\
\hline $\begin{array}{l}\text { Blood urea nitrogen }(\mathrm{mmol} / \mathrm{l}) \\
\text { Creatinine }(\mu \mathrm{mol} / 1) \\
\text { Calcium }(\mathrm{mmol} / \mathrm{l}) \\
\text { Phosphate }(\mathrm{mmol} / \mathrm{l}) \\
\text { Albumin }(\mathrm{g} / 1) \\
\mathrm{CH}_{\mathrm{so}}(\mathrm{U} / \mathrm{ml}) \\
\mathrm{C} 3(\mathrm{~g} / \mathrm{l}) \\
\text { Alkaline phosphatase }(\mathrm{IU}) \\
\text { Haemoglobin }(\mathrm{g} / \mathrm{dl}) \\
\text { Body weight }(\mathrm{kg})\end{array}$ & $\begin{array}{l}12 \cdot 1(1 \cdot 2) \\
318 \cdot 2(26 \cdot 5) \\
2 \cdot 3(0 \cdot 03) \\
1 \cdot 2(0 \cdot 03) \\
43(1) \\
19 \cdot 4(0 \cdot 5) \\
0.98(0 \cdot 02) \\
28 \cdot 4(1 \cdot 2) \\
10.5(0 \cdot 7) \\
54 \cdot 2(1 \cdot 6)\end{array}$ & $\begin{array}{l}12 \cdot 6(1 \cdot 4) \\
309 \cdot 4(35 \cdot 4) \\
2 \cdot 3(0 \cdot 05) \\
1 \cdot 2(0 \cdot 1) \\
42(1) \\
20 \cdot 1(0 \cdot 6) \\
1 \cdot 01(0 \cdot 03) \\
27 \cdot 4(1 \cdot 3) \\
10 \cdot 8(0 \cdot 6) \\
57 \cdot 3(2 \cdot 0)\end{array}$ & $\begin{array}{l}13 \cdot 0(1 \cdot 1) \\
335.9(26 \cdot 5) \\
2 \cdot 3(0 \cdot 03) \\
1.3(0 \cdot 03) \\
41(1) \\
19 \cdot 7(0 \cdot 5) \\
0.94(0.03) \\
24 \cdot 2(1 \cdot 2) \\
10 \cdot 2(0 \cdot 6) \\
54 \cdot 8(1 \cdot 6)\end{array}$ & $\begin{array}{c}21 \cdot 8(1 \cdot 4) \\
503 \cdot 9(26 \cdot 5) \\
2 \cdot 2(0 \cdot 05) \\
1 \cdot 5(0 \cdot 1) \\
41(1) \\
20 \cdot 5(0 \cdot 7) \\
0 \cdot 94(0 \cdot 03) \\
31 \cdot 1(1 \cdot 5) \\
9 \cdot 2(0 \cdot 6) \\
56 \cdot 4(2 \cdot 0)\end{array}$ & $\begin{array}{l}14.6(1.0) \\
353.6(35.4) \\
2.3(0.03) \\
1.3(0.03) \\
43(1) \\
19 \cdot 2(0.5) \\
0.96(0.03) \\
26.9(1.4) \\
10.6(0.6) \\
55.1(1.7)\end{array}$ & $\begin{aligned} 40 \cdot 0(1 \cdot 5) \\
742 \cdot 6(35 \cdot 4) \\
2 \cdot 0(0 \cdot 03 \\
2 \cdot 0(0 \cdot 06) \\
31 \quad(1) \\
18 \cdot 2(1 \cdot 1) \\
0 \cdot 86(0 \cdot 02) \\
38 \cdot 7(2 \cdot 1) \\
8 \cdot 2(0 \cdot 5) \\
52 \cdot 4(2 \cdot 1)\end{aligned}$ \\
\hline
\end{tabular}

Conversion: SI to traditional units-Blood urea nitrogen: $1 \mathrm{mmol} / 1=2.8 \mathrm{mg} / 100 \mathrm{ml}$.

Creatinine: $1 \mu \mathrm{mol} / 1 \approx 0.0113 \mathrm{mg} / 100 \mathrm{ml}$. Calcium: $1 \mathrm{mmol} / 1 \approx 4 \mathrm{mg} / 100 \mathrm{ml}$.

TABLE II-Urinary data for five Buddhist monks and five other patients (controls) with chronic renal failure. Results are means (SE) for each group for each year of the study period

\begin{tabular}{|c|c|c|c|c|c|c|}
\hline & \multicolumn{2}{|c|}{ Year 1} & \multicolumn{2}{|c|}{ Year 2} & \multicolumn{2}{|c|}{ Year 3} \\
\hline & Monks & Controls & Monks & Controls & Monks & Controls \\
\hline $\begin{array}{l}\text { Urea nitrogen }(\mathrm{mmol} / 24 \mathrm{~h}) \\
\text { Protein }(\mathrm{g} / 24 \mathrm{~h}) \\
\text { Sodium }(\mathrm{mmol} / 24 \mathrm{~h}) \\
\text { Fractional excretion of phosphate }\left({ }^{\circ}{ }^{\circ}\right) \\
\text { Phosphate }(\mathrm{mmol} / 24 \mathrm{~h}) \\
\text { Creatinine clearance }(\mathrm{ml} / \mathrm{min}) \\
\text { Total solute (mmol } / \text { day) }\end{array}$ & $\begin{array}{r}82(3 \cdot 6) \\
2 \cdot 1(0 \cdot 1) \\
59 \cdot 4(3 \cdot 7) \\
13 \cdot 2(0 \cdot 8) \\
7 \cdot 0(0 \cdot 4) \\
32 \cdot 1(1 \cdot 5) \\
250 \cdot 2(7 \cdot 7)\end{array}$ & $\begin{array}{r}139(7 \cdot 1) \\
2 \cdot 3(0 \cdot 2) \\
106 \cdot 6(6 \cdot 4) \\
21 \cdot 7(1 \cdot 2) \\
13 \cdot 2(0 \cdot 4) \\
34 \cdot 4(1 \cdot 5) \\
414 \cdot 3(10 \cdot 1)\end{array}$ & $\begin{array}{r}82(3 \cdot 6) \\
2 \cdot 3(0 \cdot 1) \\
64 \cdot 7(4 \cdot 6) \\
14 \cdot 1(0 \cdot 8) \\
7 \cdot 8(0 \cdot 4) \\
30 \cdot 7(1 \cdot 5) \\
257 \cdot 4(7 \cdot 8)\end{array}$ & $\begin{array}{c}150(10 \cdot 7) \\
2 \cdot 4(0 \cdot 3) \\
120 \cdot 5(8 \cdot 1) \\
40 \cdot 9(2 \cdot 1) \\
13 \cdot 6(0 \cdot 4) \\
21 \cdot 1(1 \cdot 4) \\
466 \cdot 4(11 \cdot 4)\end{array}$ & $\begin{array}{r}89(3 \cdot 6) \\
2 \cdot 2(0 \cdot 1) \\
61 \cdot 3(4 \cdot 4) \\
14 \cdot 9(0 \cdot 9) \\
7 \cdot 8(0 \cdot 5) \\
28 \cdot 2(1 \cdot 4) \\
246 \cdot 7(8 \cdot 1)\end{array}$ & $\begin{array}{r}146(7 \cdot 1) \\
2 \cdot 9(0 \cdot 3) \\
117 \cdot 4(7 \cdot 2) \\
48 \cdot 1(2 \cdot 0) \\
11 \cdot 4(0 \cdot 4) \\
8 \cdot 2(1 \cdot 1) \\
489 \cdot 3(11 \cdot 8)\end{array}$ \\
\hline
\end{tabular}

Conversion: SI to traditional units-Nitrogen: $1 \mathrm{mmol} 24 \mathrm{~h}=0.028 \mathrm{~g} / 24 \mathrm{~h}$. Phosphate: $1 \mathrm{mmol} / 24 \mathrm{~h}=0.03 \mathrm{~g} / 24 \mathrm{~h}$. 
and protein excretion to be in the range of 15 to $19 \mathrm{~g} /$ day. Despite this low protein intake the ratio between blood urea nitrogen and serum creatinine concentrations remained within normal ranges, possibly reflecting a low rate of creatinine production due to small muscle mass and low physical activity. These findings are in contrast to those in the controls, who progressed into terminal renal failure with uraemia over the study period. They ate three meals a day and did not meditate; their estimated protein intake was between 25 to $30 \mathrm{~g} /$ day. Admittedly, the nature of presumed glomerular disease could have been different in the two groups of patients. Based on urinary findings, serum complement, and antibody profiles, however, the diseases in both groups were not active and were perhaps clinically comparable.

It thus appears that the very low protein intake could prevent the progress of chronic renal failure. The mechanism responsible for this is not well understood. There is, however, evidence that glomerulosclerosis with nephron destruction is related to high protein intake, increased nephron blood flow, and glomerular hyperfiltration. ${ }^{8-10}$ Low protein intake may therefore have minimised glomerular hyperfiltration and prevented destruction of nephrons. Furthermore, the urinary data showed lower sodium solute excretion in the monks than in controls and would suggest that low solute load might have a protective effect on nephron destruction.

The role of phosphate intake in the progression of renal disease is also interesting. In animal experiments an increase in phosphate intake is associated with pronounced calcification and histological changes resulting in impaired renal function ${ }^{11}{ }^{12}$; these changes may be prevented by low phosphate intake. ${ }^{12}$ In man effective reduction of phosphate intake would require stringent restriction of protein intake, and this is poorly tolerated by most patients. The slow progression of renal disease in the monks could, therefore, be attributed to low phosphate as well as to low protein intake. Parathyroid hormone concentrations in the two monks were only in the upper range of normal whereas they were raised in the controls. There was less necessity for an adaptive mechanism to maintain phosphate balance. ${ }^{13}$

The consumption of one meal a day is a unique feature of the Buddhist monks' way of life. Viewed in the light of Brenner's hypothesis of glomerular hyperfiltration and glomerulosclerosis, ${ }^{8}$ consumption of one meal a day may be a more physiologically acceptable and less damaging method of taking protein than consuming it in spaced doses throughout the day. Furthermore, it should be more acceptable to patients, as a given amount of salt and protein a day eaten in one meal would offer more salt and protein per serving than if eaten in three meals, thus giving a better taste.

Finally, the well maintained clinical condition in these monks is remarkable. Judging from the general condition, blood urea nitrogen and serum creatinine ratio, serum albumin, complements, and haemoglobin concentrations, and body weight there was no evidence to indicate protein energy malnutrition. ${ }^{14}$ Although the total energy intake is not known, the amount of food consumed was small and yet it was well tolerated. In contrast, the controls had low serum albumin concentrations with evidence of protein deficiency. In addition to the minimal activities and the small muscle mass of the monks the role of meditation should also be considered. Meditation is known to decrease the metabolic rate and oxygen consumption..$^{15}{ }^{16}$ It might be that meditation well practised could simulate the state of hibernation in animals. During hibernation the need for protein is minimised as protein catabolism is diminished while protein anabolism is enhanced. ' Despite the advantageous effects of meditation in the monks, its practicality in the management of general patients with chronic renal failure is perhaps limited vecause of the difference in life style. Further study on this topic would be interesting.

This work was supported partly by Japan International Cooperation Agency, Tokyo, Japan. Miss Manee Ritdumrongphan helped in typing the manuscript.

\section{References}

${ }^{1}$ Ibels LS, Alfrey AC, Haut L, Huffer WE. Preservation of function in experimental renal disease by dietary restriction of phosphate. $N$ Engl $\mathcal{F}$ Med $1978 ; 298: 122-6$.

2 Walser M, Mitch WE, Collier VU. Calcium and phosphorus in chronic renal failure during nutritional therapy. In: Berlyne GM, ed. Contributions to nephrology. Basel: S Karger, 1980:92-102.

${ }^{3}$ Kleinknecht C, Salusky I, Broyer M, Gubler MC. Effect of various protein diets on growth, renal function, and survival of uremic rats. Kidney Int 1979;15:524-41.

4 Friend PS, Fernandes G, Good RA, Michael AF, Yunis EJ. Dietary restriction early and late: effects on the nephropathy of the NZB X NZW mouse. Lab Invest 1978;38:629-32.

${ }^{5}$ Giordano C. Early diet to slow the course of chronic renal failure. In: Zurukzoglu W, Papadimitriou M, Pyrpasopoulos M, Sion M, Zamboulis C, eds. Proceedings of eighth international congress on nephrology. Basel: S Karger, $1981: 71$.

${ }^{6}$ Maschio G, Oldrizzi L, Tessitore N, et al. Effects of dietary protein and phosphorus restriction on the progression of early renal failure. Kidney Int 1982;22:371-6.

7 Khantipalo B. Buddhism explained: an introduction to the teachings of Lord Buddha. Bangkok: Mahamkut Rajavidyalaya Press, 1973:106-42.

${ }^{8}$ Brenner BM, Meyer TW, Hostetter TH. Dietary protein intake and the progressive nature of kidney disease. $N$ Engl f Med 1982;307:652-9.

${ }^{9}$ Lalich JJ, Faith GC, Harding GE. Protein overload nephropathy in rats subjected to unilateral nephrectomy. Archives of Pathology 1970;89: 548-59.

10 Hostetter TH, Olson JL, Rennke HG, Venkatachalam MA, Brenner BM. Hyperfiltration in remnant nephrons: a potentially adverse response to renal ablation. Am $\mathcal{F}$ Physiol 1981 ;241 :F85-93.

11 MacKay EM, Oliver J. Renal damage following the ingestion of a diet containing an excess of inorganic phosphate. $\mathcal{F}$ Exp Med 1935;61:319-33.

12 Haut LL, Alfrey AC, Guggenheim S, Buddington B, Schrier N. Renal toxicity of phosphate in rats. Kidney Int 1980;17:722-31.

13 Bricker NS, Fine LG. The renal response to progressive nephron loss. In: Brenner BM, Rector FC Jr, eds. The kidney. 2nd ed. Philadelphia: WB Saunders, 1981:1056-96.

14 Harvey KB, Blumenkrantz MJ, Levine SE, Blackburn GL. Nutritional assessment and treatment of chronic renal failure. Am f Clin Nutr 1980; 33:1586-97.

15 Wallace RK. The physiological effects of transcendental meditation. Los Angeles: MIU Press, 1973.

${ }^{16}$ Karambelkar PV, Vinekar SL, Bhole MV. Studies on human subjects staying in an air-tight pit. Indian $\mathcal{F}$ Med Res 1968;56:1282-7.

17 Nelson RA. Urea metabolism in the hibernating black bear. Kidney Int $1978 ; 8$ suppl:177-9.

(Accepted 29 April 1983)

A 65 year old fit man with no personal or family history of gout suddenly developed the condition in the knee after meniscectomy, with a raised serum uric acid concentration. What might be the cause and how should he be treated?

Gout may occur with no personal or family history of the disease. Whereas the metatarsophalangeal joint of the big toe is the most common first joint to be affected by gout, any previously traumatised joint may be the first to develop the disease. While this patient's raised serum uric acid concentration gives some support to the diagnosis of gout, it is not impossible that he had calcium pyrophosphate crystals released in the joint after the meniscectomy and subsequent exercises and that this might have caused the acute effusion. It would help to know whether crystals were identified in the synovial fluid. A first attack of gout usually only requires nonsteroidal anti-inflammatory drugs for a few days to clear up the attack and it may be some years before the second attack. Treatment of hyperuricaemia is indicated only with repeated attacks of gout, considerably raised uric acid concentrations, evidence of renal impairment, or in people in hot dry climates. A small supply of your favourite gout drug (colchicine, indomethacin, phenylbutazone, naproxen, etc) kept in reserve for the next acute attack, weight reduction, and a high fluid intake and output might be all that are necessary. A reduction in protein containing foods would reduce his exogenous source of uric acid, and offal should be avoided. Some diuretiss produce pronounced hyperuricaemia, and for patients taking one for hypertension a change to a beta-blocker is advisable.J M GUMPEL, consultant physician (rheumatology), London. 